\title{
Protecting Working-Age People with Disabilities: Experiences of Four Industrialized Nations
}

\author{
Richard V. Burkhauser \\ Cornell University and University of Melbourne \\ Mary C. Daly \\ Federal Reserve Bank of San Francisco, IZA Bonn, \\ and USC Schaeffer Center \\ Nicolas Ziebarth \\ Cornell University, IZA Bonn, and DIW Berlin
}

June 2015

Working Paper 2015-08

http://www.frbsf.org/economic-research/publications/working-papers/wp2015-08.pdf

\section{Suggested citation:}

Burkhauser, Richard V, Mary C. Daly and Nicolas Ziebarth. 2015. "Protecting Working-Age People with Disabilities: Experiences of Four Industrialized Nations.” Federal Reserve Bank of San Francisco Working Paper 2015-08. http://www.frbsf.org/economicresearch/publications/working-papers/wp2015-08.pdf

The views in this paper are solely the responsibility of the authors and should not be interpreted as reflecting the views of the Federal Reserve Bank of San Francisco or the Board of Governors of the Federal Reserve System. 


\title{
Protecting Working-Age People with Disabilities: Experiences of Four Industrialized Nations
}

\author{
Richard V. Burkhauser \\ Cornell University and University of Melbourne \\ Mary C. Daly \\ Federal Reserve Bank of San Francisco, IZA Bonn, and USC Schaeffer Center \\ Nicolas Ziebarth \\ Cornell University, IZA Bonn, and DIW Berlin
}

June 3, 2015

\begin{abstract}
Burkhauser received partial funding for his work on this paper from the Rehabilitation Research and Training Center on Disability Statistics and Demographics at Hunter College, which is funded by the National Institute on Disability and Rehabilitation Research (NIDRR, Federal Award \# H133B120006). The contents of this paper do not necessarily represent the policy of NIDRR and readers should not assume endorsement by the Federal Government (Edgar, 75.620 (b)) or the Federal Reserve Bank of San Francisco or the Federal Reserve Board of Governors. We thank Jan Maarten van Sonsbeek for data on the Netherlands, Marten Palme and Lisa Laun for data on Sweden, and Dr. Lueg as well as Ms. Kühnapfel from the German Insurance Association (Gesamtverband der Deutschen Versicherungswirtschafte) for their data on private disability insurance policies and other background information on Germany. We also thank Aline Passlack and Catherine van der List for excellent research assistance. We have no financial interests that constitute a conflict of interest with this research.
\end{abstract}

Corresponding author: Mary C. Daly, email: mary.daly@sf.frb.org. 


\begin{abstract}
Although industrialized nations have long provided public protection to working-age individuals with disabilities, the form has changed over time. The impetus for change has been multifaceted: rapid growth in program costs; greater awareness that people with impairments are able and willing to work; and increased recognition that protecting the economic security of people with disabilities might best be done by keeping them in the labor market. We describe the evolution of disability programs in four countries: Germany, the Netherlands, Sweden, and the United States. We show how growth in the receipt of publicly provided disability benefits has fluctuated over time and discuss how policy choices played a role. Based on our descriptive comparative analysis we summarize shared experiences that have the potential to benefit policymakers in all countries.
\end{abstract}




\section{Introduction}

All industrialized nations provide some form of public protection to working-age individuals with disabilities. In their early manifestations, these programs focused on easing the financial consequences of disability by providing cash assistance in lieu of full-time work. Over time a number of nations have moved away from simple cash assistance to emphasize pro-work programs designed to help individuals with disabilities maintain their labor market connections. On balance these changes have reflected concerns about rapid growth in program rolls as well as increased awareness that many individuals with disabilities can remain productive in the labor market.

In this paper, we describe the evolution of disability programs in four countries: Germany, the Netherlands, Sweden, and the United States. We select these countries as examples of nations with similar goals but very different approaches to achieving them. We begin by comparing trends in disability recipiency across countries. We find that all four countries experienced pronounced fluctuations in disability recipiency rates over the past 40 years. We show that these fluctuations are difficult to explain based on the relatively stable paths of variables such as health and population composition. We go on to describe changes in disability policy in each country and show that these changes are well correlated with the ups and downs in country disability recipiency rates. We interpret these correlations as suggestive of a link between policy and disability recipiency and summarize lessons that can be gleaned from the experiences in each nation. Although our paper is simply a descriptive comparative analysis, it highlights the similarities of experiences across nations and underscores the potential benefit of learning from other countries’ policy reform efforts when tackling the challenges associated with providing social protection to those with disabilities. 


\section{Disability Program Growth across Countries}

The number of workers receiving disability-based social insurance has increased substantially in most industrialized nations over the past 40 years. Population growth accounts for part of this increase, but disability caseloads as a share of the working-age populationknown as the disability recipiency rate-also have risen substantially. ${ }^{1}$ This can be seen in Figure 1, which shows the total number of people receiving long-term categorical disability income benefits as a share of the working-age population in our four countries. ${ }^{2}$ This is the most critical number to policymakers since it measures the magnitude of the fiscal burden that these disability programs place on country finances. ${ }^{3}$ We show values beginning in 1970 through the last year of public data available in each country. ${ }^{4}$ We provide a more detailed description of the data in Appendix A.

Figure 1 plots the level of disability recipiency over time for each country. In 1970, disability recipiency rates in our three European Union (EU) nations were considerably higher-

\footnotetext{
${ }^{1}$ Pattison and Waldron (2013) argue that population growth explains the bulk of the rise in disability recipiency (the Social Security Disability Insurance (DI) program) in the United States. Duggan and Imberman (2009) and Burkhauser et al. (2014) remove the influence of population growth and consider the factors that explain the remaining rise in the program. Since population growth alone would not put additional financial pressure on the system, knowing what these other factors are is critical to policymakers tasked with funding the system. Most recently Liebman (2015) argues that most of the increase in the DI incidence rate, controlling for other factors including unemployment rates, occurred in the 1980s. Since then this controlled measure of incidence has leveled off, but at a substantially higher rate than in the early 1970s.

${ }^{2}$ The U.S. disability recipiency rate only includes beneficiaries receiving Social Security DI. When SSI-disabled adults and DI program beneficiaries are combined, the level of the U.S. disability recipiency rate is higher, but the patterns over time are roughly the same. This point is demonstrated in Burkhauser et al. (2013), Figure 2.

${ }^{3}$ The fiscal burden of disability programs comes from the fact that beneficiaries receive income support and generally do not contribute to the tax base since they are largely out of the labor force.

${ }^{4}$ Disability caseloads data are made public with a considerable lag in some countries. Hence we cannot fully document how the global financial crisis affected recipiency rates in all countries.
} 
4.2 percent in Germany, 2.4 percent in the Netherlands, and 3.5 percent in Sweden - than they were in the United States-1.2 percent). Since then disability recipiency rates have risen substantially in each country with the exception of Germany. However, as the figure highlights, they have done so along significantly different trajectories.

To see these dynamics more clearly, Table 1 provides average annual growth rates in disability recipiency by decade and over the entire sample. As the table shows, disability recipiency rates rose in all countries during the 1970s, with especially rapid growth in the Netherlands and more modest growth in Germany. In contrast, in the 1980s, recipiency rates grew more modestly and even fell in the United States and Germany. By the 1990s, growth in the Netherlands and Germany ended and disability recipiency rates fell, on balance, over the decade. During the 2000s, disability recipiency rates continued to fall in the Netherlands and Germany and grew less quickly in Sweden. Growth in the United States slowed slightly but remained quite high relative to the EU countries in our sample.

The final average (1970-final) shows that, after smoothing through the fluctuations in growth over the decades, the United States experienced the highest average annual growth rate over the sample period. The rapid growth in our three EU countries brought on program reforms and a tempering or reversal of the path of disability recipiency. In contrast, with the exception of the 1980s, growth in U.S. disability recipiency was nearly continuous over the sample period.

Of course one possible explanation for the differences in growth across countries is that health and population characteristics have evolved differently for each nation over time. To understand the extent to which these factors might account for the growth in disability recipiency shown in Figure 1 and Table 1, we compare trends in self-reported health across countries and more formally evaluate the role that demographics and other changes in the population eligible 
for disability benefits might account for trends in disability recipiency rates. We begin by examining trends in self-reported health over time and across countries. Although the selfreported measure is prone to response biases, which are well documented in the literature, one strength is its availability across countries and over time. ${ }^{5}$ McGee et al. (1999) show that selfreported health is highly correlated with objective health measures and is a very reliable indicator of mortality.

Figure 2 contains OECD data on self-reported health status for each of our countries. The plot shows the percentage of the population aged 45-64 in each country reporting that they are in very good or good health on a survey that asks respondents to state whether they are in very good, good, fair, or poor health. Since the incidence of disability increases with age this is the most relevant age group for examining the role of health in disability benefit trends.

Although there are persistent differences across countries in the percent of individuals reporting very good or good health, there is little variation over time within countries. Over the past ten years the overall prevalence of very good or good health among working-age populations has remained relatively steady in each country. The relative stability of the health measure in each of our sample countries suggests that changes in the prevalence of impairments in the working-age population is unlikely to account for the bulk of the fluctuations in disability recipiency rates within and across countries found in Figure 1 and Table 1. Findings reported in Börsch-Supan and Jürges (2012) come to the same conclusions.

A second reason disability recipiency rates may have varied across countries over time is that the eligible populations in those nations may have evolved differently. Examples of this

\footnotetext{
${ }^{5}$ Some of the differences across countries may relate to the age structure of the population. Older populations report lower rates of good health than younger populations. Remaining differences are likely to result from reporting differences that are idiosyncratic to each country (e.g., Jürges, 2007; Ziebarth, 2010a; Van Soest et al., 2011).
} 
include increased labor force participation among women in the United States, which increased the share of women eligible for Social Security Disability Insurance (DI) benefits. However, previous research has found that accounting for these factors cannot fully explain the differences in levels and trends across countries. See, for example, Burkhauser et al. (2014) and OECD (2010).

If neither health nor population characteristics can account for all of the cross-country differences in disability recipiency rates, either levels or trends, then what can? An obvious possibility is policy. ${ }^{6}$ In what follows we show how changes in disability policy and its implementation in each country are correlated with the dynamics of disability recipiency rates documented in Figure 1. While our comparative descriptive analysis falls short of establishing a causal effect of policy on the disability rolls, it is suggestive of the potential impact of policy design on the trends in disability benefit receipt across and within the countries in our sample.

\footnotetext{
${ }^{6}$ We are not the first to make this point. The OECD (2010) summary of disability program growth across OECD nations concludes that policy rather than population characteristics are behind the rapid expansion of disability benefit receipt in most nations. The point is also emphasized by Autor and Duggan (2010) and Burkhauser and Daly (2011, 2012) for the United States and Burkhauser et al. (2014) cross-nationally, and Duggan and Imberman (2009). Liebman (2015) acknowledges that policy can matter but argues this is less the case for the United States since the 1990s.
} 


\section{Disability Policy and Program Growth}

In industrialized nations, social protection from income loss associated with disability is just one part of a broader social safety net designed to protect working-age individuals from the loss of labor market income. Countries also provide protection to those who lose market income for other reasons such as unemployment or old age.

In general, countries provide this protection in tiers associated with the expectations of employment for different groups. The first tier provides universal, long-term, needs-based cash transfers that guarantee a social minimum income to all families. The second tier provides cash support to those available for employment and expected to work, but who are temporarily unemployed. These benefits are usually conditional on past work, limited in duration, and may be needs-based. The third tier targets benefits to those not expected to work-the aged, disabled, etc.- - and can either be needs-based or based on past earnings. Since recipients of these benefits are not expected to return to employment, benefits are typically higher and not time limited.

When these tiers provide substantially different amounts of income and their categories are mutable, a considerable responsibility falls on program gatekeepers to consistently determine who should come onto the program. For retirement programs this is straightforward; age is an arbitrary but easily verifiable eligibility marker. Eligibility determinations by program gatekeepers will be straightforward and program caseloads will be predictable based on knowable trends in population composition.

Disability is more difficult. Unlike retirement, there is no precise definition or easily verifiable marker for determining categorical eligibility for long-term disability benefits. Moreover, disability is not a static concept and social conceptualizations of disability evolve over time. For example, over the past 20 years the medical model of disability underlying categorical 
disability programs in most OECD countries has been rejected and replaced by a conceptualization that recognizes that the social environment is as important as health in determining an individual's ability to participate in society (WHO, 2001). ${ }^{7}$ Under this model, "work disability" is a changeable state that depends on a number of factors, including an individual's health-based impairment, the level of accommodation offered in the workplace, and the relative economic rewards associated with working or exiting the labor force to receive disability benefits.

The fluid nature of the disability category has meant that changes to disability policy parameters such as who is covered for program benefits, the level of benefits - both absolutely and relative to alternative programs or wage earnings - and the breadth and severity of the qualifying conditions can influence caseload growth and disability recipiency rates. This potential is especially acute in the context of reductions in other forms of social protection or changes in the broader economy.

For example, in a number of industrialized nations, the relative value of disability benefits has risen significantly over time, as policymakers have cut payments or imposed stricter eligibility criteria on other benefit programs including unemployment insurance and general welfare. Structural changes in the economy including the declining job and wage prospects for low-skilled workers also have made disability benefits more attractive as means of long-term income support. Finally, disability benefits have increasingly become an option for displaced or long-term unemployed workers dislocated during economic downturns. Since very few disability beneficiaries ever return to the labor market, the growth in the rolls that occurs during and after

\footnotetext{
${ }^{7}$ There is no clear consensus on the most appropriate conceptualization of disability, although the most widely used is the World Health Organization's (WHO) International Classification of Disability, Health, and Functioning (WHO, 2001). Burkhauser and Schroeder (2007) propose a method to harmonize classifications in surveys.
} 
recessions account for some of the long-term increase in disability recipiency rates. These rates then remain elevated until these recession induced cohorts of beneficiaries age out of the system or die. For a more detailed discussion of these issues in OECD nations see OECD (2010).

Below we discuss how disability program designs and changes in disability policy parameters in three EU countries (Germany, the Netherlands, and Sweden) and in the United States are related to disability recipiency rates in each country. When relevant we also discuss how these policy structures may have interacted with macroeconomic conditions and the broader social safety net to account for growth in the disability rolls. For reference, Figure 3 (Panels A through D) show disability recipiency rates along with major policy changes over time for each country. Table 2 provides key information about the current state of disability programs in each nation.

\subsection{The German Experience}

Germany, like most European nations, has a long-standing first-tier universal needs-based cash transfer program that provides a guaranteed social minimum income floor to all its citizens. Benefits are funded out of general revenues. Major reforms in 2004 fundamentally altered Germany's tier 1 program to impose job search and job training requirements on beneficiaries. ${ }^{8}$ In general, tier I beneficiaries are considered "able to work" and part of the active labor force in Germany. ${ }^{9}$ Benefits levels are set nationally and vary across individuals based on household size and composition.

\footnotetext{
${ }^{8}$ The 2004 reforms created the Arbeitslosengeld II program, generally referred to as "Hartz IV" (Sozialgesetzbuch II, "Social Code Book II"). For more information about the reforms see, e.g., Eichhorst et al., 2008; Konle-Seidl, 2012.

${ }^{9}$ People are considered "able to work" if they are judged to be able to work at least three hours per day. A relatively small share of people receive Sozialhilfe (Hilfe zum Lebensunterhalt)
} 
Germany also provides second- and third-tier benefits. Second-tier benefits consist primarily of unemployment insurance (UI). To receive unemployment benefits workers must have been employed for at least 24 months prior to applying. Unemployed workers under the age of 50 are paid benefits (Arbeitslosengeld I) for up to 12 months. After age 50 the maximum duration increases gradually with age such that workers who are age 58 at the start of their unemployment spell receive up to 24 months of benefits. For workers without children, the replacement rate for unemployment benefits is 60 percent of the average monthly wage earnings over the previous year; unemployed workers with children receive 67 percent of prior earnings. Unemployment benefits are funded by payroll taxes up to the annual social insurance contribution ceiling of $€ 72,600$ (\$87,000). ${ }^{10}$ Employers and employees each pay 1.5 percent of the gross wage.

Third-tier benefits in Germany include the Statutory Old-Age Pension Scheme (OAP) and the Work Disability Pension (WDP) for both partially and totally disabled workers. Both programs pay benefits to workers who have paid into the systems during their work life. Similar to UI, employers and employees are each subject to a payroll tax-9.35 percent of their monthly gross wages up to the social insurance contribution ceiling. In 2014, total WDP benefits per month were about $€ 11$ billion, or 4.2 percent of total OAP/WDP spending (DRV, 2014a, b, c; BMAS, 2014). ${ }^{11}$

("Social Assistance Benefits") of a similar amount but have no job search requirement and are not considered to be in the labor force ( $\$ 27-40$ SGB XII). These beneficiaries are typically "long-term unemployed" and classified as temporarily not able to work three hours per day.

${ }^{10}$ In the eastern states of Germany, the rates are the same but the annual social insurance ceiling is lower-€62,400 (\$75,000).

${ }^{11}$ The amount of $€ 11$ billion is based on an indirect calculation multiplying the 78,689 partial WDP beneficiaries by their average annual cash benefit of $€ 5,844$ and adding the 1,224,177 full WDP beneficiaries multiplied by their average annual benefit received of $€ 8,604$ (DRV, 2014a, b, c). 
In Germany, like other EU countries, workers also are eligible for both short- and longterm statutory sickness insurance benefits. ${ }^{12}$ While these benefits can be the gateway to WDP, they are not considered tier 3 programs since they are time limited. Employers are required to provide short-term sickness benefits. Workers who are determined to be eligible for short-term sick benefits (up to six weeks) receive 100 percent of their net wages (Ziebarth and Karlsson, 2010, 2014). ${ }^{13}$ Workers with longer spells are reevaluated for access to long-term sickness benefits. These publicly funded benefits replace 70 percent of net wages and can be paid for up to 78 weeks. See Ziebarth $(2009,2013)$ for additional details.

Germany had the highest recipiency rates in the early 1970s of the four countries we compare in Figure 1. One reason for these higher rates was a change in WDP rules in 1969 that allowed partially disabled workers to receive full WDP benefits if they were unable to find a job (Burkhauser and Hirvonen, 1989). Further expansions in 1972 extended coverage to housewives and the self-employed and allowed disabled workers to transition to the retirement program at age 62 without an actuarial reduction in benefits. As can be seen in Panel A of Figure 3, disability recipiency rose significantly in the aftermath of the reforms, peaking at 5.8 percent in 1984.

A substantial tightening of WDP coverage criteria followed this rapid growth in recipiency rates. WDP reforms in the early 1980s limited coverage to workers who had paid payroll taxes into the system over the past three out of five years and had accumulated at least

\footnotetext{
12 Similar to the workers' compensation program in the United States, Germany also has a separate Statutory Accident Insurance (SAI) program covering temporary and permanent work absences in case of work accidents or diseases. But unlike the United States it is administered at the federal rather than the state level.

${ }^{13}$ Short-term sick leave benefits were cut to 80 percent of wages in October 1996 but this costsaving reform was politically unsustainable and was reversed in 1999. For a discussion see Ziebarth and Karlsson (2014).
} 
five years of market work experience. Since many housewives did not meet these "market work criteria," this greatly curtailed their WDP coverage. Hence a large fraction of the decline in disability recipiency rates during this period was due to the reduction in access for women working outside the paid labor market. (See RKI, 2006, and Börsch-Supan and Jürges, 2012, for a more detailed discussion.) In the aftermath of these system coverage reforms, growth in disability recipiency turned negative (Table 1), more than undoing the increases in disability recipiency rates over the previous decades (Figure 3, Panel A).

Additional reforms were launched in the 1990s and 2000s. Actuarial reductions and caps on the earnings of WDP beneficiaries were introduced in 1996. Börsch-Supan and Jürges (2012) report that new male WDP beneficiaries fell from an average of about 150,000 per year prior to these reforms to 75,000 per year thereafter. This 50 percent per year reduction in the inflow of new male beneficiaries to the program contributed to the decline in disability recipiency rates over the rest of the decade evidenced in Figure 3 Panel A and Table $1 .^{14}$

Another round of structural WDP reforms was introduced in 2001. Most important was the tightening in the work-limited eligibility standard from "being unable to work in the occupation in which one was trained-effectively in the last job or a comparable job in terms of the skills it required, the wages it paid and its prestige"- to "being unable to work in any job available in the economy". As we will describe later, this reform made eligibility for WDP insurance benefits stricter than the criteria for the typical private market disability benefit. Following this policy change, inflows (men and women combined) to the WDP program decreased further, falling from 200,000 in 2001 to 160,000 in 2005. This slow but steady decline

\footnotetext{
${ }^{14}$ Note that these numbers reflect the stock of all beneficiaries. As such, even large declines in the flow of new beneficiaries only gradually translate into declines in the overall disability recipiency rate.
} 
in new beneficiaries is linked to additional declines in the overall disability recipiency rate in Germany (Krause et al. 2013; DRV, 2014b).

WDP reforms in 2004 continued to focus on reducing the flow of new recipients into the program. However, the attention of these reductions shifted away from tightening WDP eligibility requirements and towards promoting worker accommodation on the job. Specifically, the reforms mandated that employers provide workplace reintegration in the event of a worklimiting impairment. Indeed, the law requires that when an impaired worker exhausts his/her short-term sickness benefits (six weeks) and is being considered for longer-term sickness benefits, employers must coordinate a plan that includes input from the sick-listed employee, WDP experts, the appropriate worker council, and the workplace physician. The plan is meant to ensure that the worker's temporary disability can be overcome and to prevent future reductions in work capacity.

The experience of Germany over the past four decades is a useful illustration of the role that policy decisions can play in the dynamics of disability recipiency rates. When Germany was expanding both the coverage and generosity of disability benefits, recipiency rates were high and rising relative to other countries. WDP program growth subsequently declined in the aftermath of reforms that limited access, made benefits less attractive, and required employers to implement a workplace reintegration program. Germany is the only country in our sample whose disability recipiency rate is now below its 1970 level. As can be seen in the bottom row of Table 1, annual growth rates over the entire period of our analysis (1970 to our most recent year of data) averaged -0.73 percent in Germany compared to +2.69 percent in the Netherlands, +2.3 percent in Sweden, and +3.1 percent in the United States. 
Private Disability Insurance. Notably, the policy changes in Germany that reduced the size of the public WDP program were correlated with an increase in the market for private disability insurance (Figure 4). This private market insurance generally provides benefits to covered workers who have established that a health shock led to reduced work capacity in the current (or a comparable) occupation—a less difficult level of work incapacity to meet for benefit eligibility than the one imposed by WDP since 2001. As shown in Figure 4, the number of new private disability insurance policies in Germany grew slowly from 1976 through the mid1990s. But growth increased substantially around the introduction of actuarial reductions and caps on the earnings of WDP beneficiaries in 1996. Growth in new private policies increased further in 2001. This is the year that WDP eligibility was limited to workers who were unable to perform any work in the economy. ${ }^{15}$ In 2012, 61 percent of employed men and 42 percent of employed women were covered by private disability insurance (Statistika, 2014). ${ }^{16}$

While the expansion of private disability insurance suggests that many Germans responded to the reductions in WDP benefits by purchasing alternative private policies, to our knowledge no research on this substitution has been published. Even if individuals are augmenting the WDP program with private insurance, the substitution is likely not perfect. Private disability insurance plans are experience rated and individually underwritten. Private disability insurance follows private insurance law and is based on a private contract between the insurer and the insured, which specifies the conditions for the insured risk individually.

\footnotetext{
${ }^{15}$ Conversations with German Association of Insurers (GDV) representatives confirm that no industry-specific supply-side factors have been driving this trend.

${ }^{16}$ Beneficiaries of private disability insurance may also receive WDP benefits if they are eligible. This contrasts with the U.S. market where private insurers may reduce payments dollar-for-dollar for recipients of public Social Security Disability Insurance. This means that private insurers in Germany have more of an incentive to return beneficiaries to work than do those in the United States. (See Burkhauser and Daly, 2011, for a fuller discussion of this point.)
} 
Premiums depend on age, medical diagnoses, and occupation. As a result, premiums can be high for high-risk occupations and applicants may be denied coverage.

\subsection{The Netherlands ${ }^{17}$}

As in Germany, the disability system in the Netherlands contains both a social insurance program that protects workers against lost labor earnings and a program that provides a social minimum for disabled adults with little or no work history. A separate social minimum scheme for the disabled self-employed ended in 2004. The Dutch social insurance program (WAO/WIA) provides cash transfers to working-age men and women based on lost labor earnings. The Netherlands does not have a separate program similar to workers' compensation in Germany, Sweden, or the United States. Rather it has a longer-term disability transfer program that, together with sickness benefits, all private firms must offer; the program provides a comprehensive system of both partial and total disability benefits to workers regardless of how or where their disability occurred. The Dutch also have a categorical disability-based welfare program (Wajong) that, unlike the general welfare scheme, is not means tested. This program is similar to the SSI-disabled adults program in the United States in that it targets men and women whose disabilities occurred prior to their entrance into the labor force and are severe enough that they have not engaged in full-time employment as adults. (See Table 2 for details of the disability program in the Netherlands.)

The Dutch disability program grew rapidly over the 1970s. This was a time when the system provided relatively generous benefits (Figure 3, Panel B). In the 1970s, government payments from the universal sickness benefit-essentially a universal short-term disability

${ }^{17} \mathrm{~A}$ longer version of this summary of the Dutch system can be found in Burkhauser and Daly (2011). 
system—replaced up to 80 percent of net-of-tax wage earnings for up to one year. And most employees (90 percent) had the rest of their net-of-tax earnings replaced by collective-bargaining agreements with their employers. These disability replacement rates were far in excess of comparable programs in the United States and many other European nations. Sickness benefits were payable for up to 12 months. After that, employees still receiving benefits were eligible for disability benefit screening. Workers with chronic conditions that caused a reduction in their capacity to perform work commensurate with their job training and work history were eligible for disability benefits. Those judged fully disabled were eligible for benefits equal to 80 percent of their previous before-tax earnings. Those judged partially disabled (those with some residual earnings capacity) were eligible for partial benefits; the minimum degree of impairment for eligibility was 15 percent.

In a significant loosening of access to full disability benefits in the mid-1970s, Dutch courts determined that unless disability evaluators could prove otherwise, they were required to attribute a partially disabled worker's lack of employment to discriminatory behavior. The result was that it became "administrative practice" to treat unemployed, partially disabled persons as if they were fully disabled. That interpretation of the law made assessing lost earnings capacity unnecessary beyond the minimum 15 percent, since that became sufficient to entitle a person to full benefits. This essentially made the Dutch partial disability system a very generous full disability program. During this period, the adjusted disability recipiency rate in the Netherlands grew 11.45 percent per year (Table 1 and Figure 3, Panel B).

Reforms initiated between 1982 and 1987 were the first of three major efforts over the next two decades to regain control of the Dutch disability transfer system. By 1985, a series of cuts in the replacement rate effectively lowered it from 80 percent of before-tax income to 70 
percent of after-tax income for both new entrants and current beneficiaries. In 1987 the labor market consideration rule was completely abolished. Despite the legal ban on including labormarket considerations in their assessments, disability adjudicators still tended either to grant or deny full benefits. Denial rates remained quite low, suggesting that the legal change did not stop the de facto use of labor-market considerations in the adjudication process. Nonetheless these changes were accompanied by slower growth in disability recipiency in the 1980s that brought the Netherlands more in line with disability growth in Sweden.

In 1994, the Dutch government introduced several additional reforms including measures to further tighten eligibility criteria, which caused the recipient rate to decline. And in a new policy, private firms were made responsible for an employee's first six weeks of sick pay. The introduction of some privatization of the disability system was new in the Netherlands and represented a change in policy intended to encourage firms to provide accommodation, rehabilitation, and continued employment opportunities to workers as an alternative to moving them onto long-term cash benefits. The length of time mandated for firms to bear the full responsibility for sick pay was extended from six weeks to one year in 1996. Despite these reforms, the Dutch disability recipiency rate stopped declining in 1997 and began to slowly climb.

In 2002, the Dutch disability system began to phase in the third and most significant set of reforms. These reforms culminated in the establishment of a new disability insurance scheme in 2004-WIA — which replaced the WAO scheme that had been in place since 1967. These systemic reforms fundamentally altered disability policy in the Netherlands. The reforms deliberately made work rather than cash benefits the expectation and enforced this by increasing 
the incentives of both employees and their employers to invest more time and effort in accommodation and rehabilitation following the onset of a disability.

Foremost among these reforms was the extension of the mandated length of time that firms (including small employers) had to bear full responsibility for employees’ sick pay from one year to two years. These changes effectively meant that during the first two years following a health shock, workers were the responsibility of the firm and not eligible for long-term government-provided disability benefits. During these two years, employers were required to allow workers receiving sickness benefits to remain with the firm; dismissal was allowed only for employees who refused to cooperate in a reasonable work-resumption plan.

The reforms also gave firms a list of prescribed rehabilitation and accommodation activities that they (via a private occupational health agency) had to provide to assist workers in remaining on the job or finding alternative employment. When the two years were complete, workers were allowed to apply for long-term disability benefits, but they were required to provide documentation regarding return-to-work efforts during the two-year period. In 2007, nearly 14 percent of disability insurance claims were returned to employers, and the employer continued to be responsible for employing the worker until the claim was processed or the worker had returned to the old or a new job.

Reforms at the front end of the process were accompanied by significant reforms in the longer-term benefit program. All employers were made to pay for the full and permanent disability program through a uniform pay-as-you-go premium rate. Employers also had to pay to fund the publicly run partial disability program, but they could opt out of it by enrolling their workers with a private insurer instead. Either way, employers had to pay experience-rated premiums that covered the first ten years of partial disability benefit receipt. After ten years, the 
financial burden would shift to the uniform pay-as-you-go rates that also cover the fully and permanently disabled and the stock of current beneficiaries under the old system.

Borghans et al. (2014) provide evidence that the reduction in benefits for current Dutch disability insurance recipients in the reforms of 1992-1993 have led to both their increased use of alternative social welfare programs and greater earnings from employment over the next decade. They argue that, on average, increased income from these two alternative sources fully offset the cut in their DI benefits. While it is still too early to determine the full effect of more recent policy changes on the Dutch disability beneficiary population, Van Sonsbeek and Gradus (2011) provide the first micro-simulation of the consequences of the post-2002 round of policy changes discussed above. They estimate that the combined impact of the introduction of experience rating together with the introduction of the statutory Gatekeeper Protocol and stricter examinations will reduce the projected long-term number of disability beneficiaries by 600,000. They project that the introduction of the new WIA scheme will further reduce that number by 250,000 by 2040, as compared with a no-change scenario. Koning and Lindeboom (2015) provide the most recent view of the consequences of the Dutch disability reforms on program enrollment and a review of the literature on this topic.

Overall, research on the effectiveness of the Dutch disability reforms supports the ideas that policy design matters for the outcomes of individuals with impairments and suggests that, with assistance, many workers who experience a health shock can remain productively in the labor market.

\subsection{Sweden}


Like most European nations Sweden has a long-standing first-tier universal needs-based cash transfer program that provides a guaranteed social minimum income floor to all its citizens. This first-tier protection is funded out of general revenue and is available to everyone who lives or works in Sweden. Although benefits provide minimum income to anyone in need, applicants apply for benefits based on income and particular circumstances, such as disability, parental needs, or old age. Benefits are set nationally and indexed to keep pace with the price level.

Sweden also provides second- and third-tier benefits. The second tier in Sweden includes unemployment insurance benefits, which include both a mandatory and voluntary component. The mandatory component is paid for by all employers and replaces a minimum fraction of wages for covered workers. The number of weeks covered by unemployment insurance has fluctuated over time but is generally longer than in the United States. Most individuals also are covered by voluntary unemployment insurance that is negotiated between firms and trade unions. Somewhat uniquely among the countries we review, Sweden also has many private options for unemployment insurance; these may be purchased individually or through an employer.

Sweden provides third-tier benefits, including old-age pensions and sickness and disability benefits, through a combination of programs. For those with an earnings history the bulk of the protection is provided based on a social insurance program that, as in the United States, is financed by statutory employer and employee contributions. Many employers in Sweden also pay into occupational-based insurance and pension programs on behalf of their employees. Participation in these schemes is driven by competitive forces or collective bargaining agreements with unions but a majority of employers in Sweden participate in these programs. See Table 2 for more details about the Swedish disability system. 
As in the Netherlands, the Swedish disability program was relatively generous and expanding rapidly in the 1970s (see Table 1). The first level of protection for Swedish workers with health problems is a sickness benefit. In the 1970s, sickness benefits replaced about 90 percent of expected earnings for individuals with "abnormal physical or mental conditions" that reduced their normal work capacity by at least 25 percent. Workers claiming sickness absence for more than eight days were required to get a certificate from a doctor. This was primarily facilitated by the individual's doctor with no centralized screening or standards.

After one year, employees still receiving benefits could apply for long-term disability insurance. Workers with functional limitations that caused a reduction in their capacity to perform work commensurate with their job training and work history were eligible for disability benefits. Benefits were awarded for partial (50 percent) and full disability. For those under age 60, benefits included rehabilitation and vocational training. For those 60 and older, beneficiaries were provided income support. Like sickness benefits, disability benefits were very generous, replacing the vast majority of expected lost earnings.

Over the course of the 1970s, standards for obtaining long-term disability benefits were also loosened to make it easier for the long-term unemployed to move onto the program. For workers of all ages, unemployment spells of more than one year were added to the list of criteria considered in the disability screening process. For workers over age 60, long-term unemployment became a sufficient condition for moving onto disability benefits, even without a certifiable functional limitation. Similar to the Dutch case, these changes meant that the 
disability benefit program was increasingly being used as a very generous long-term unemployment insurance program. ${ }^{18}$

Generous benefits and easier access correlated with steady growth in disability recipiency rates over the 1970s and 1980s (Figure 3, Panel C). These features also left the program vulnerable to growth related to the serious recession in the early 1990s. As shown in Figure 3, Panel C, following the foreign exchange crisis in 1990 and ensuing deep recession, disability recipiency rates surged. Policymakers responded by lowering the replacement rates on sickness benefits, making employers pay for the first 14 days of sickness absence, and removing the pure labor market criteria for disability benefits for older workers. With these changes to policy and an improving economy, disability recipiency rates stabilized for most of the rest of the decade. That said, they remained quite high and at a level that policymakers argued was unsustainable. As such, additional policy reforms were made throughout the 1990s. These reforms were designed to increase the employer cost of worker sickness absence and increase the threshold for workers applying for sickness and/or disability benefits. ${ }^{19}$

Facing increasing fiscal pressures and a renewal of disability recipiency rate growth (Figure 3, Panel C), in 2000 the Swedish government proposed much more sweeping reforms to the sickness and disability system. Despite considerable opposition from various advocacy groups, significant reforms were put into place over the remainder of the decade. The driving

\footnotetext{
${ }^{18}$ Econometric studies of the Swedish system support this view. See for example Rebick (1994), Larsson (2002).

${ }^{19}$ The Swedish government made numerous changes to sickness benefit replacement rates, the number of days the employer paid for employee sickness absence, and the number of days the worker had to wait before receiving sickness benefits (Andren, 2003). In addition, policymakers removed most of the special allowances for disability insurance afforded to unemployed and older workers Jönsson et al. (2011).
} 
principle behind the reforms was that work support, rather than cash assistance in lieu of work, was the primary goal of disability policy.

This general principle translated into a number of important specific reforms. In 2003, the government merged the sickness benefits and disability systems and began a series of changes to standardize and enforce the administration of these now joint systems. Most notable among them was the centralization of screening processes. Up until this point, certification for sickness benefits had been variable as had disability benefit allowance rates. Although rehabilitation and vocational training were goals, many doctors and regional disability gatekeepers focused on providing income support rather than employment retraining. By centralizing the process and developing standardized protocols for granting cash benefits, policymakers were better able to regulate the gatekeepers and enforce the strategy of promoting participation in work before offering cash benefits. Although it is too early to judge its effectiveness, the idea is that this standardization will temper the link between regional economic conditions and disability recipiency that had historically been present.

In addition to standardizing the screening process, the merger of the sickness and disability programs forced disability gatekeepers to become actively involved early in the process. By getting vocational and rehabilitation experts involved early at the sickness benefit stage, policymakers intended to stem the flow of new applicants to the long-term disability program. To aid in this process, sickness benefits were capped at one year, and beneficiaries were evaluated for work ability at 180 days of absence. Only those who could show that they had no capacity to perform any job were allowed to remain on the program for the full year. In addition, employers were required to work with disability administrators to create a rehabilitation plan. And gatekeepers were given the power to demand that employers provide certification 
about the types of accommodations they made for the worker. In the aftermath of these reforms, the use of sickness benefits declined as did the flow of new beneficiaries into the long-term disability system. This correlation between policy changes and declines in benefit use, to our knowledge, has not been causally established in published research.

In 2008 the Swedish government undertook an additional series of reforms to its sickness and long-term disability programs (these reforms are detailed in Hartman 2011 and OECD 2009). These reforms were meant to further curb growth in the rolls and more actively return newly impaired workers back to the labor market. The 2008 reforms went beyond engaging gatekeepers and employers and focuses on individuals with disabilities. New rules were aimed at strengthening the incentives for individuals with disabilities to work and improving their opportunities to do so. The principal reform was the establishment of a new timeline for the provision of rehabilitation services under the sickness absence program, with checkpoints closely aligned with assessment of work capacity and a reduction of the cash value of sickness benefits for those who did not return to work. In addition to adding more checkpoints, the reforms also front-loaded the evaluations so that they were being done at 3-, 6-, and 12-month increments. The earlier checkpoints provided rehabilitation, counseling, and assessment much closer to the onset of an impairment when return to work was more likely.

After the reforms, new sickness program entrants returned to work more quickly and reduced their overall time on the program (Hartman 2011). In contrast, few of those already on the sickness program when the new reforms were initiated ever returned to work. When their sickness benefits ended they simply moved onto other social assistance programs. These findings provide support for the idea that early intervention matters. Waiting even one year following the onset of impairment significantly reduces the chance that rehabilitation will result in a return to 
work. The disability reforms put in place by the Swedish government late in the 2000s appear to have helped curb growth in disability recipiency rates in the nation (Figure 3, Panel C).

\subsection{The U.S. Experience}

Unlike the three EU countries discussed above, the United States has no first-tier universal needs-based cash transfer program that provides a guaranteed social minimum income floor to all its citizens. The Supplemental Security Income (SSI) program, which is limited to the aged, disabled adults, and parents of disabled children, is the only long-term needs-based cash transfer program. ${ }^{20,21}$ The only other major categorical needs-based cash transfer program in the United States is Temporary Assistance for Needy Families (TANF), which is targeted at single mothers, provides an even lower guaranteed income level, and limits the guarantee to five years.

The second tier in the United States includes unemployment insurance benefits, which replace a fraction of wages for covered workers for short periods of time. In normal economic times, unemployment benefits can last up to 26 weeks. During recessions, this maximum is often extended, and it rose to 99 weeks in the aftermath of the global financial crisis. Unemployment insurance benefits are generally higher than SSI or TANF benefits.

The social security old-age retirement insurance (OAI) and disability insurance (DI) programs make up the third tier of benefits in the United States; they provide social insurance to

\footnotetext{
${ }^{20} \mathrm{SSI}$ is similar in design to the Dutch categorical disability-based welfare program (Wajong), but its income guarantee level is substantially lower.

${ }^{21}$ The SSI aged and disabled adult programs share the same categorical eligibility criteria applied for the earnings-based retirement or Old-Age Insurance (OAI) and Disability Insurance (DI) programs. Individuals with sufficiently low earnings records may jointly qualify for OAI and SSI aged benefits and for DI and SSI disabled adult benefits. This said, these programs are generally treated separately by policymakers.
} 
workers who have paid social security taxes over their working life. ${ }^{22}$ To be eligible for benefits, workers must have accumulated sufficient quarters of coverage, as defined in the Social Security Administration's (SSA) pension rules. These requirements are sufficiently strict to limit OAI and DI benefits to those with substantial attachments to the labor market. (For a summary of the benefit requirements and rules, see SSA 2013b.) Benefit levels from these programs are based on past earnings and can be substantially higher than the social minimum level of benefits guaranteed by the SSI aged and disability programs.

Eligibility for DI benefits requires applicants to meet a federal disability standard applied by administrative evaluators and adjudicators located in each state. The criteria are in principle quite strict. Eligibility requires that a worker be "unable to perform any substantial gainful activity on any job in the economy for at least one year.” There is no benefit for partial disability. Disability benefits are intended to be a last resort for those with permanent and total impairments. See Table 2 for more details on the U.S. DI program.

Although the written eligibility criteria have not changed over time, their implementation has changed in a direction that has increased the number of working-aged adults receiving disability benefits. Indeed, many of the disability recipiency rate fluctuations shown in Figure 1 and Table 1 line up with changes in SSA policy that made it easier or harder to gain entry to the DI rolls. For example, rapid disability recipiency rate growth in the 1970s aligns with Congressional actions that increased the replacement rate for a disabled worker with median earnings from 35 to 49 percent (Figure 3, Panel D). In the late 1970s and early 1980s disability recipiency rates fell, first because program gatekeepers were urged to interpret existing rules more strictly, and then because Congress in 1980 required the SSA to reevaluate all current

${ }^{22}$ Autor et al. (2014) provide a detailed analysis and discussion of the private disability insurance market in the United States, which is significantly smaller than the private market in Germany. 
recipients to see if they still met the medical standards. This rule change, which was rigorously enforced by the SSA at the start of the new Reagan administration, resulted in a drop in the DI rolls despite a major recession—-the substantial drop in normalized adjusted disability recipiency rates in the United States between 1978 and 1983 are in stark contrast to the sizable growth in these values before 1978 and after 1990 (Figure 3, Panel D).

By 1983 the widespread reevaluation of those already on DI was halted as the courts and then Congress restricted the SSA's power to reevaluate beneficiaries. Furthermore, in 1984, responding to a backlash against restrictive cuts imposed in the Social Security Disability Amendments of 1980, policymakers expanded the ways in which a person could medically qualify for the DI program. The 1984 legislation moved away from a strict medical listing determination of eligibility to one that also considered an applicant's overall medical condition and ability to work. In addition, the legislation allowed for symptoms of mental illness and pain to be counted when assessing DI eligibility, regardless of whether the person had a verifiable medical diagnosis (Figure 3, Panel D). ${ }^{23}$

The expansion of eligibility to impairments that were more difficult to measure and do not precisely meet the medical listings means that SSA has increasingly been tasked with making more subjective decisions about the impact that presenting impairments might have on an applicant's work ability. For applicants who do not meet or exceed the medical listings, program administrators consider a set of vocational criteria. While these vocational criteria have been in place over the history of the DI program, their use by program gatekeepers to determine benefit eligibility has risen dramatically since 1991. Currently, they are used to justify the majority of new awards, especially among those with the more difficult to determine conditions of mental

\footnotetext{
${ }^{23}$ See Berkowitz and Burkhauser (1996) for more discussion of these changes and their effects.
} 
illness and musculoskeletal conditions - the primary condition of more than 50 percent of all newly enrolled beneficiaries (Burkhauser and Daly, 2011).

One consequence of expanding eligibility beyond identifiable medical listings is that DI applicants and gatekeepers have much more of a role in determining program growth. For example, over time the cyclical sensitivity of DI application rates has risen considerably. Applications rise during recessions and fall during periods of economic growth (see Rupp and Stapleton, 1995; Stapleton et al. 1998; Black et al. 2002; Autor and Duggan, 2003; Liebman, 2015). But as can be seen in Figure 3, Panel D, increased applications generally result in an increase in disability recipiency rates which do not subside as economic conditions improve since, once they enter, very few beneficiaries ever leave the program.

In addition to the cyclical sensitivity of disability applications and awards, evidence has shown a secular rise in the number of workers who apply over time related to the unintentional increase in the replacement rates of DI for low-wage workers (Autor and Duggan, 2003). Bound and Burkhauser (1999) provide an early review of the literature on the labor supply effects of disability insurance. Since then researchers have consistently found a negative effect of DI program work constraints on employment—see especially Chen and van der Klaauw (2008) and von Wachter et al. 2011. Again, since few beneficiaries ever leave the rolls to return to work, the surge in disability recipient rates associated with business cycle fluctuations or economic restructuring has generally translated into a long-term increase in disability recipiency rates in the working-age population.

Finally, there is evidence that the strictness of DI gatekeepers also varies. Using SSA administrative records, Maestas et al. (2013) estimate that 23 percent of applicants are initially accepted or denied based on whether they were assigned an easier or a stricter Disability 
Determination Services gatekeeper rather than on differences in the status of their health or impairment status.

\subsection{Why Has the German Experience Been So Different?}

As seen in Figure 1 and discussed above, recipiency rates in Germany’s WDP program fell between 1984 and reunification in 1989 and have almost continuously done so since then. This pattern stands in contrast to the Netherlands, Sweden, and the United States where recipiency rates have increased considerably since the 1970s. While the rates in the Netherlands and Sweden have come down from recent peaks of 7.4 percent in 2003 (Netherlands) and 9.6 percent in 2005 (Sweden) they reached a new record high of 4.2 percent in the United States in 2011. As a result Germany now has the lowest recipiency rates of government-provided disability insurance benefits among these four nations.

What accounts for the decline in Germany both in its rates over time and relative to other countries? Our read of the data is that the relatively restrictive coverage and eligibility conditions that Germany has imposed over time have shifted the costs of disability insurance coverage, especially since 2001, to individuals and their employers. This shift is evident in the fact that over 60 percent of male and 40 percent of female employees contract for private disability insurance to augment their public insurance coverage. In addition, WDP benefits, when available, have declined in value over time. This reduction in the social safety net for workers with disabilities has been cited as contributing to the high poverty rates among public disability beneficiary households (Krause et al. 2013).

Another more positive reason for the decline is that Germany has increasingly moved towards a model of "rehabilitation before pension," emphasizing the overall focus on 
maintaining work ability. As a result, Germany has one of the largest medical rehabilitation markets. In 2011, 1.9 million rehabilitation therapies were prescribed, and a total of €8.9 billion is spent annually (cf. Ziebarth, 2010b, 2014). This commitment to rehabilitating workers while they are receiving temporary earning replacement as part of their sickness benefits may have played a role in curbing growth in the WDP program.

Finally, the German social insurance scheme is part of a larger context of protection and expectations for workers with disabilities. Germany has a coexisting Disability Classification System (DCS) which is codified in Social Code Book IX (SGB IX) and entitled "Rehabilitation and Participation of Handicapped Workers.” ${ }^{24}$ This DCS system identifies citizens with health impairments and assigns them a handicap rating by medically based impairment categories. Only permanent health impairments lead to a classification. For example, a mild form of Parkinson's disease without balance issues but with "mild motion disorders" yields a disability degree of 3040 percent whereas more severe forms of Parkinson's lead to degrees of 50 percent and above (BMAS, 2009). A person with a rating of 50 percent and above is officially classified as "severely handicapped." 25 The SGB IX then provides disadvantage compensation (Nachteilsausgleich) for severely handicapped people such as special income tax deductions, the ability to retire two years earlier without deductions, and parking lots for wheelchair users. Effectively, all WDP beneficiaries are eligible for these benefits without any loss of WDP benefits before retirement since WDP is not means tested. ${ }^{26}$

\footnotetext{
24 Before 2001, this was the Schwerbehindertengesetz.

${ }^{25}$ People with handicap ratings from 30 to 50 percent who have difficulty finding a job can apply for the workplace quota system described below.

26 Aarts et al. (1998) and Börsch-Supan and Jürges (2012) discuss pathways from early retirement to full retirement in the German system. Börsch-Supan and Jürges (2012) focus exclusively on Germany and provide a detailed discussion of its pathways to retirement. Unlike the WDP, Nachteilsausgleich offers those defined as severely handicapped a pathway to
} 
In fact, almost 1 million people who are officially classified as severely handicapped work full time in Germany (BA, 2014). This outcome may be related, at least partly, to the quota system that mandates employers with more than 19 full-time employees to ensure that at least 5 percent of their employees are classified as severely handicapped. Employers not complying with the quota must pay a monthly penalty (Ausgleichsabgabe) of €290 per unoccupied workplace. This effectively means that a small business with 20 full-time employees has to hire one severely handicapped worker or pay an annual penalty of $\$ 4,500$. Lalive et al. (2013), using data from Austria, which has a similar quota system, show that it significantly increases the employment of handicapped people. ${ }^{27}$

\section{What Can We Learn from These Experiences?}

An important issue for policymakers in all countries facing the challenges of providing protection for workers with disabilities is that disability programs, even if not generous, are essential income for many individuals. In countries where other components of the social safety net are weaker or less generous, disability benefit programs are even more difficult to challenge. The U.S. experience highlights this point.

However, the policy outcomes of Germany, the Netherlands, and Sweden we have discussed show that this is a very static view. It assumes that in the absence of benefits, individuals with disabilities would remain out of the labor market, dependent on other forms of public or private assistance for support. Disability reforms in these countries over the past decade

retirement two years earlier than non-handicapped people without actuarial penalty. In the context of the three-tier system we view this option as a tier 1 benefit equal to the deductions that are typically applied in case of early retirement, i.e., 7.2 percent of the last wage.

${ }^{27}$ Unlike for other countries, there is a notable absence of research on the German disability system and in particular the behavioral effects of policy choices. 
provide suggestive empirical support that increased employment will occur when pro-work policies replace policies that have had the opposite effect. Their reform experiences show that a significant number of people with disabilities, who would otherwise have moved onto long-term cash benefits, were able, with reasonable levels of support, to return to work (OECD, 2010). While it is always the case that tightening the criteria for disability benefits runs the risk of denying disability benefits to those who will not be able to find work, on balance the EU experience suggests that reasonable pro-work policies will both substantially reduce disability recipiency rates and increase the employment of those who would otherwise have been on the long-term disability rolls.

Another concern is that programs like disability insurance are especially important in economic downturns when individuals with limited work capacity are not only more likely to be laid off but are less likely to find a new job. Past experience of EU countries, especially Germany and the Netherlands, that intentionally or unintentionally used this logic to turn their long-term disability programs into more general unemployment programs, suggests that it can be a very expensive and ultimately ineffective policy decision. Indeed, many EU nations continue to struggle to regain control over their disability systems which for many decades have been used as long-term unemployment insurance programs. A key message from the EU experience is that explicitly divorcing long-term "unemployability” insurance from disability insurance is critical to effectively target resources towards both populations.

Together the experiences of other nations suggest that it is possible to balance the competing goals of providing social insurance against adverse health shocks and maximizing the work effort of all working-age adults with and without disabilities. Past disability policies in both the United States and EU countries have focused more on the former than the latter, resulting in 
rapid growth in disability transfer populations that outpaced growth in the economy. Efforts to shift to more pro-work policies over the past decade in Europe suggest that fundamental disability reforms, if done well, can lower projected long-term costs for taxpayers, ease the job of disability administrators, and importantly, improve the short- and long-run opportunities of people with disabilities. 


\section{References}

Aarts, Leo J.M., Richard V. Burkhauser, and Philip R. de Jong. 1998. Convergence: A Comparison of European and United States Disability Policy.” Terry Thomason, John Burton, and Douglas Hyatt (eds.), New Approaches to Disability in the Work Place. IRRA Research Volume, pp. 299-338.

Andren, D. 2003. Sickness-Related Absenteeism and Economic Incentives in Sweden: A History of Reforms. https://www.cesifogroup.de/pls/guestci/download/CESifo\%20DICE\%20Report\%202003/ CESifo\%20DICE\%20Report\%203/2003/dicereport3-03-reform-models-3.pdf, accessed January 10, 2015

Autor, D. H. and Duggan, M. G. 2003. The rise in disability recipiency and the decline in unemployment. The Quarterly Journal of Economics, 118(1): 157-205.

Autor, D. H. and Duggan, M. G. 2010, Supporting Work: A Proposal for Modernizing the U.S. Disability Insurance System, The Hamilton Project and Center for American Progress: Washington, D.C.

Autor, D. H., Duggan, M. and Gruber, J. 2014. Moral Hazard and Claims Deterrence in Private Disability Insurance, American Economic Journal: Applied Economics, 6(4): 110-141.

Berkowitz, E. D., and Burkhauser, R. V. 1996. A United States perspective on disability programs. In L. J. M. Aarts, R. V. Burkhauser, \& P. R. de Jong (Eds.), Curing the Dutch disease: An international perspective on disability policy reform, (pp. 71-92). Aldershot, Great Britain: Avebury, Ashgate Publishing Ltd.

Black, D, Daniel, K, and Sanders, S. 2002. The impact of economic conditions on participation in disability programs: Evidence from the coal boom and bust. American Economic Review, 92, 27-50.

Borghans, L., Gielen, A.C. and Luttmer, E.F.P. 2014. Social Support Substitution and the Earnings Rebound: Evidence from a Regression Discontinuity in Disability Insurance Reform. American Economic Journal: Economic Policy, 6(4): 34-70.

Bound, J., and Burkhauser, R. 1999. Economic Analysis of Transfer Programs Targeted on People with Disabilities. Handbook of Labor Economics, 3(C): 3417-3528.

Börsch-Supan, Axel and Jürges, Hendrik 2012. Disability, Pension Reform, and Early Retirement in Germany," NBER Chapters, in: Wise, D. A. Social Security Programs and Retirement around the World: Historical Trends in Mortality and Health, Employment, and Disability Insurance Participation, pp. 277-300. 
Bundesagentur für Arbeit (BA) 2014. Arbeitsmarket in Zahlen: Beschäftigungsstatistik, Schwerbehinderte Menschen in Beschäftigung (Anzeigeverfahren SGB IX) Deutschland 2012, https://statistik.arbeitsagentur.de/ last accessed on January 11, 2015.

Bundesministerium für Arbeit uns Soziales (BMAS) 2014. Rentenversicherungsbericht 2014, www.bmas.de, last accessed on January 11, 2015.

Bundesministerium für Arbeit uns Soziales (BMAS) 2009. Versorgungsmedizin-Verordnung, http://www.bmas.de/DE/Service/Publikationen/k710-anhaltspunkte-fuer-die-aerztlichegutachtertaetigkeit.html, last accessed on January 11, 2015.

Burkhauser, R. V. and Daly, M. C. 2011, The Declining Work and Welfare of People with Disabilities: What Went Wrong and a Strategy for Change, AEI Press, Washington, D.C.

Burkhauser, R. V. and Daly, M.C. 2012, 'Social Security Disability Insurance: Time for fundamental change’, Journal of Policy Analysis and Management, 31(2): 454-461.

Burkhauser, Richard V., Mary C. Daly, and Brian T. Lucking. 2013, “Is Australia One Recession Away from a Disability Blowout? Lessons from Other Organisation for Economic Co Operation and Development Countries.” Australian Economic Review, 46 (3): 357-368.

Burkhauser, R. V., Daly, M.C., McVicar, Duncan, and Roger Wilkens 2014, 'Disability benefit growth and disability reform in the US: lessons from other OECD nations’, IZA Journal of Labor Policy, 3 (4): 1-30.

Burkhauser, Richard V. and Hirvonen, P. 1989. United States Disability Policy in a Time of Economic Crisis: A Comparison with Sweden and the Federal Republic of Germany, The Milbank Quarterly, 67(2): 166-194.

Burkhauser, Richard V. and Mathis Schroeder. 2007. A Method for Comparing the Economic Outcomes of the Working-Age Population with Disabilities in Germany and the United States.” Schmollers Jahrbuch: Journal of Applied Social Science Studies, 127 (2): 227258.

Deutsche Rentenversicherung (DRV) 2014a. Rentenversicherung in Zahlen 2014, http://www.deutscherentenversicherung.de/cae/servlet/contentblob/238692/publicationFile/61815/01_rv_in_z ahlen_2013.pdf, last accessed on January 11, 2015.

Deutsche Rentenversicherung (DRV) 2014b. Erwerbsminderungsrente: Das Netz für alle Fälle,9th edition, http://www.deutscherentenversicherung.de/Allgemein/de/Inhalt/5_Services/03_broschueren_und_mehr/01_br oschueren/01_national/erwerbsminderungsrente_das_netz_fuer_alle_faelle.html, , last accessed on January 11, 2015. 
Deutsche Rentenversicherung (DRV) 2014c. Statistik der Deutschen Rentenversicherung, Rentenbestand am 31.12.2013, Band 197 http://www.deutsche-rentenversicherung.de/ last accessed on January 11, 2015.

Duggan, M. and Imberman, S. 2009. Why Are the Disability Rolls Skyrocketing? The Contribution of Population Characteristics, Economic Conditions, and Program Generosity, in David Cutler and David Wise, Health at Older Ages: The Causes and Consequences of Declining Disability among the Elderly. Chicago, IL: University of Chicago Press.

Eichhorst, W. and Grienberger-Zingerle, M. and Konle-Seidl, Regina 2008. Activation Policies in Germany: From Status Protection to Basic Income Support, in: Eichhorst, Werner and Kaufmann, Otto and Konle-Seidl, Regina: Bringing the Jobless into Work?, p. 17-67.

Hartman, L. 2011. "Swedish Policies for the Disabled: What Do We Know About the Effects?"Mimeo, prepared for the "Labour Activation in a Time of High Unemployment" November 13-15, 2011, hosted jointly by the University of Maryland and the OECD. http://umdcipe.org/conferences/LaborActivationParis/Papers/Laura\%20Heartmans\%20dr aft\%20paper_11_1108.pdf, last accessed October 18, 2012.

Jönsson, L., Palme, M., \& Svensson, I. (2011). Disability Insurance, Population Health and Employment in Sweden (No. w17054). National Bureau of Economic Research.

Jürges, Hendrik 2007. True health vs. response styles: exploring cross-country differences in self-reported health. Health Economics, 16(2), 163-178.

Koning, P. and Lindeboom, M. 2015. The Rise and Fall of Disability Insurance Enrollment in the Netherlands. Journal of Economic Perspectives, 29(2): 151-172.

Konle-Seidl, Regina (2012): Unemployment assistance in Germany, International labor brief, 10(9): 13.

Krause, Peter, Ehrlich, Ulrike and Möhring, Katja, (2013), Erwerbsminderungsrentner: sinkende Leistungen und wachsende Einkommensunterschiede im Alter, DIW Wochenbericht, 80(24): 3-9.

Lalive, Rafael, Wuellrich, Jean-Philippe and Zweimüller, Josef 2013. Do Financial Incentives Affect Firms’ Demand For Disabled Workers?," Journal of the European Economic Association, 11(1): 25-58.

Larsson, L. (2002), Sick of being unemployed? Interactions between unemployment and sickness insurance in Sweden, Working paper 2002:6, Institute for Labour Market Policy Evaluation (IFAU), Uppsala.

Liebman, J. B. 2015. Understanding the Increase in Disability Insurance Benefits Receipt in the United States. Journal of Economic Perspectives, 29(2): 123-150. 
Maestas, N., Mullen, K. J. and Strand, A. (2013) Does Disability Insurance Receipt Discourage Work? Using Examiner Assignment to Estimate Causal Effects of SSDI Receipt, American Economics Review 103(5): 1797-1829.

McGee, D. L., Liao, Y., Cao, G., Cooper, R. S. 1999. Self-Reported Health Status and Mortality in a Multiethnic US Cohort. American Journal of Epidemiology. 149, 41-46.

Organisation for Economic Co-operation and Development (OECD) 2009, Sickness, Disability and Work: Keeping on Track in the Economic Downturn-Background Paper, OECD, Paris, viewed May 2013, www.oecd.org/dataoecd/42/15/42699911.pdf

Organisation for Economic Co-operation and Development (OECD) 2010, Sickness, Disability and Work: Breaking the Barriers: A Synthesis of Findings across OECD Countries, OECD Publishing. DOI: 10.1787/9789264088856-en

Pattison, D., \& Waldron, H. 2013. Growth in New Disabled-Worker Entitlements, 1970-2008. Social Security Bulletin, 73(4), 25.

Rebick, M. 1994. Social security and older workers' labor market responsiveness: the United States, Japan and Sweden, in: R. Blank, ed., Social Protection versus Economic Flexibility: Is There a Trade-Off? (University of Chicago Press, Chicago).

Robert Koch Institut (RKI) 2006. Gesundheitsbedingte Frühberentung, Gesundheitsberichterstattung des Bundes, Heft 30, Statistisches Bundesamt. http://www.rki.de/DE/Content/Gesundheitsmonitoring/Gesundheitsberichterstattung/The menhefte/fruehberentung_inhalt.html, last accessed on January 11, 2015.

Rupp, K., \& Stapleton, D. (1995). Determinants of the growth in the Social Security Administration's disability programs: An overview. Social Security Bulletin. 58: 43-70.

Social Security Administration 2013, The 2013 Annual Report of the Board of Trustees of the Federal Old-Age and Survivors Insurance and Federal Disability Insurance Trust Funds, Washington, D.C., viewed May 2013, <http://www.ssa.gov/oact/tr/2013/tr2013.pdf>.

Statistika, 2014. Anteil der Berufstaetigen in Deutschland, die eine Berufsunfaehigkeitsversicherung abgeschlossen haben. http://de.statista.com/statistik/daten/studie/237869/umfrage/umfrage-zum-abschlusseiner-berufsunfaehigkeitsversicherung-nach-geschlecht/, last accessed on January 15, 2015.

Stapleton, D., Coleman, K., Dietrich, K., \& Livermore, G. (1998). Empirical analyses of DI and SSI application and award growth. In K. Rupp \& D. Stapleton, Eds. Growth in disability benefits (pp. 31 -92). Kalamazoo, Michigan: W.E. Upjohn Institute for Employment Research. 
Van Soest, Arthur, Tatiana Andreyeva, Arie Kapteyn and James P. Smith. 2011. "Self-Reported Disability and Reference Groups," NBER Chapters, in: Investigations in the Economics of Aging, pages 237-264. National Bureau of Economic Research, Inc.

Van Sonsbeek, J. M. and R. Gradus 2011, 'Estimating the Effects of Recent Disability Reforms in The Netherlands’, Tinbergen Institute Discussion Papers 11-121/3, Tinbergen Institute.

von Wachter, T., Song, J. and Manchester, J. 2011. Trends in Employment and Earnings of Allowed and Rejected Applicants to the Social Security Disability Insurance Program. American Economic Review. 101(7): 3308-3329.

World Health Organization (WHO) 2001, International Classification of Disability, Health and Functioning, Geneva, Switzerland.

Nicolas R. Ziebarth, 2009."Langzeitkranke verlieren durch Kürzung des Krankengeldes fünf Milliarden Euro," DIW Wochenbericht, German Institute for Economic Research, 76(20): 326-332.

Ziebarth, N.R., 2010a. Measurement of Health, Health Inequality, and Reporting Heterogeneity. Social Science \& Medicine. 71(1), 116-124.

Ziebarth, N. R. 2010b. Estimating Price Elasticities of Convalescent Care Programmes,” The Economic Journal, 120(545): 816-844.

Ziebarth, N. R. 2013. "Long-Term Absenteeism and Moral Hazard - Evidence from a Natural Experiment,”Labour Economics, 42: 277-292.

Ziebarth, N. R. 2014. “Assessing the Effectiveness of Health Care Cost Containment Measures: Evidence from the Market for Rehabilitation Care,” International Journal of Health Care Finance \& Economics, 14(1): 41-67.

Ziebarth, N. R. and Karlsson, M. 2010. A Natural Experiment on Sick Pay Cuts, Sickness Absence, and Labor Costs, Journal of Public Economics, 94(11-12): 1108-1122.

Ziebarth, N. R. and Karlsson, M. 2014. "The Effects of Expanding the Generosity of the Statutory Sickness Absence Insurance,” Journal of Applied Econometrics, 29(2): 208230. 


\section{Figure 1. Growth in Disability Recipiency Across Countries}

Percentage

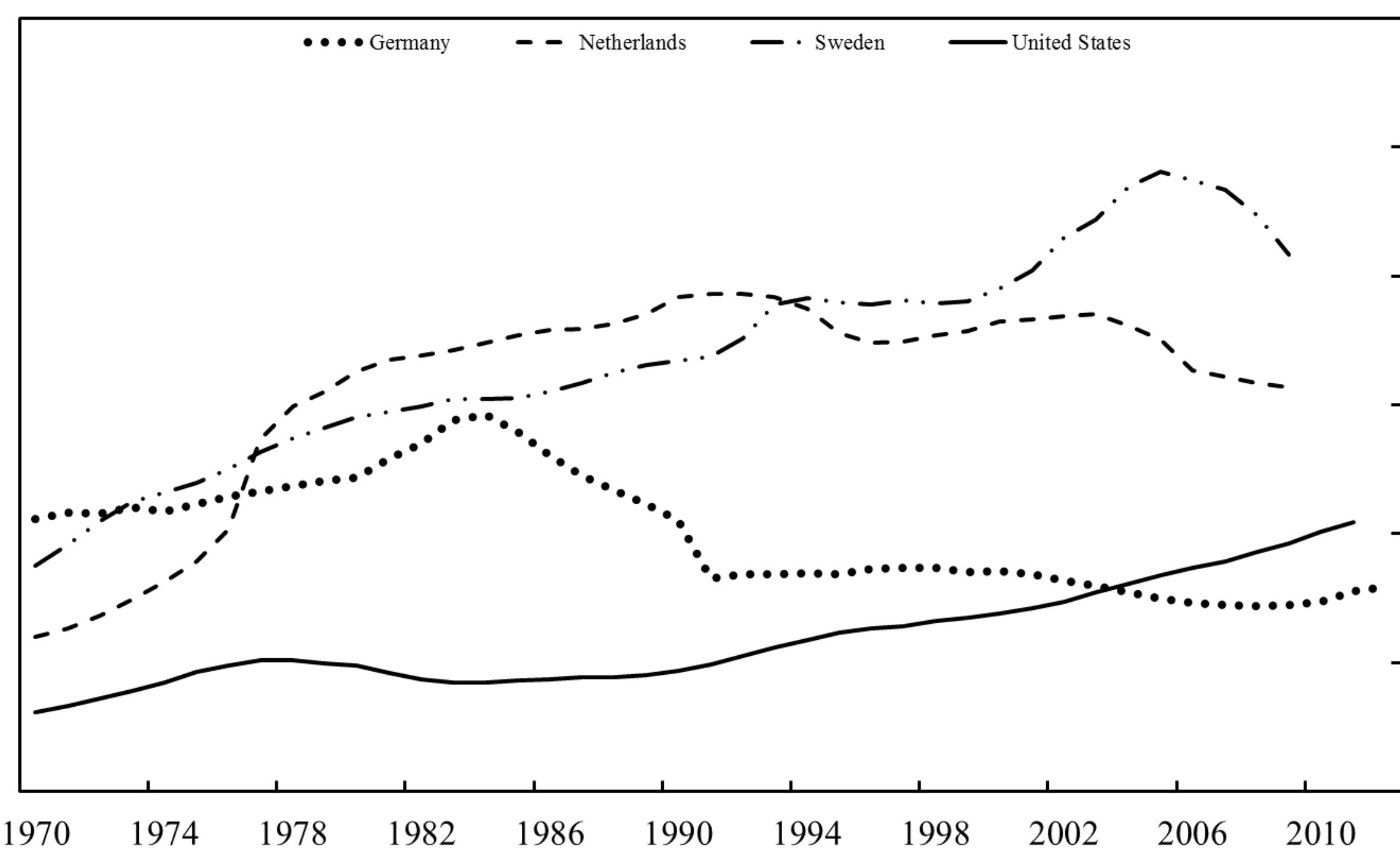

Source: Deutsche Rentenversicherung (2014a, b, c), Statistisches Bundesamt (2014), Social Security Administration, US Census Bureau; Statistics Sweden and Swedish Social Insurance Agency yearbooks, Statistics Netherlands, and the Institute of Employee Benefit Schemes 
Figure 2. Trends in Self-Reported Health Across Countries, Ages 45-64

$\%$ population reporting good or very good health

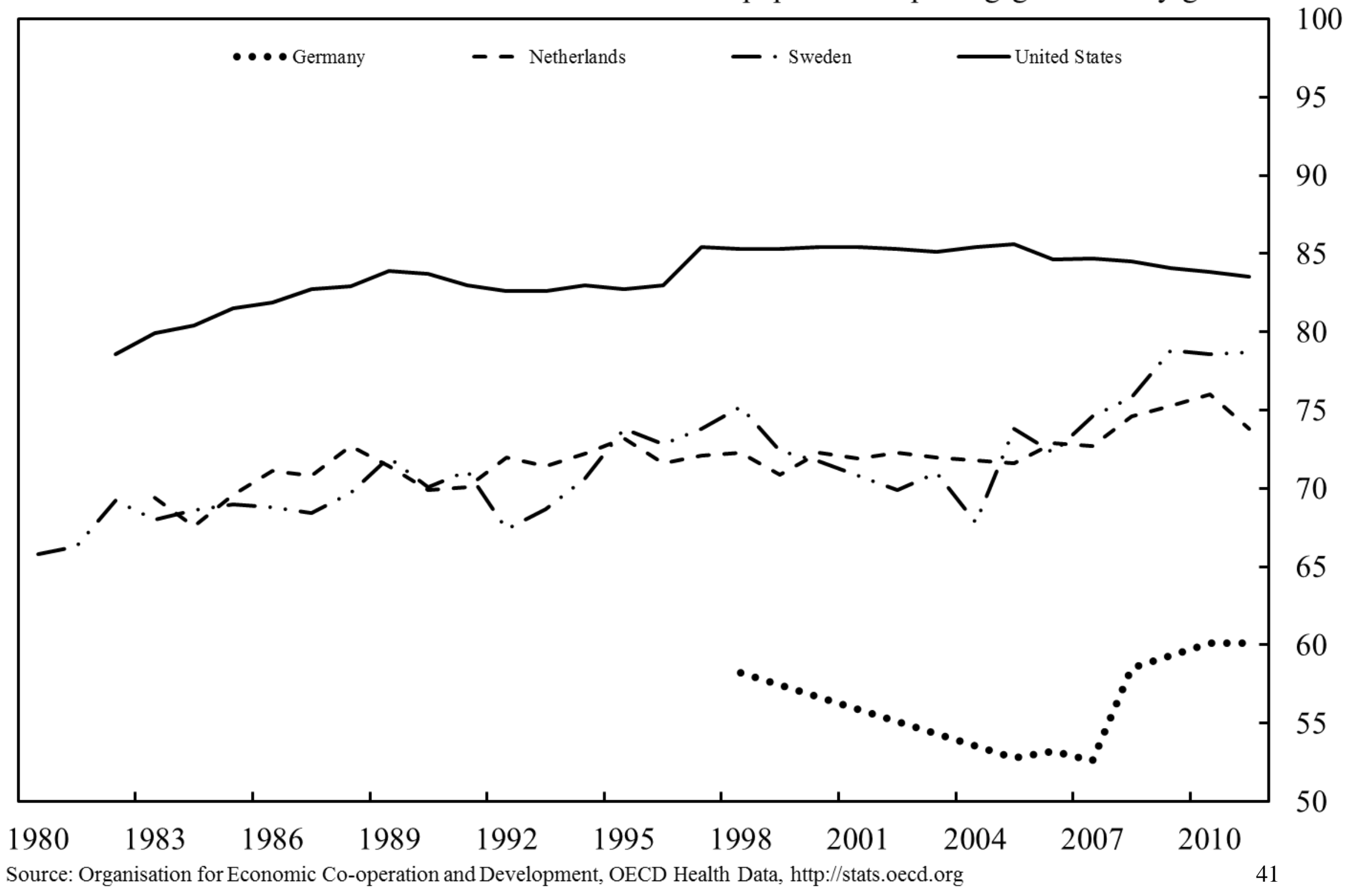


Figure 3. Development of Disability Recipiency by Country and Related Reforms

\section{Panel A. Germany DI Recipients per 100 Working Age}

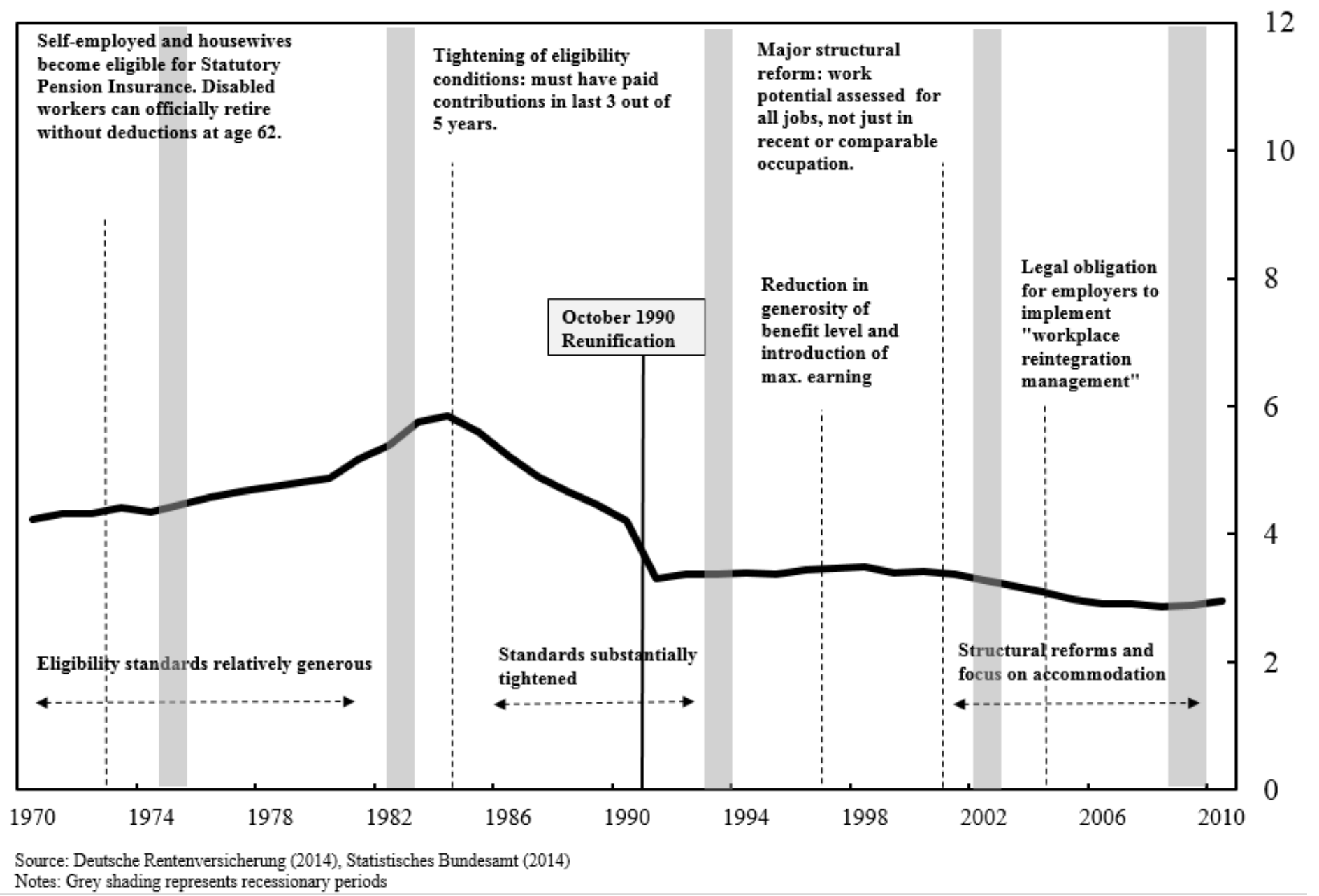




\section{Panel B. Netherlands DI Recipients per 100 Working Age}

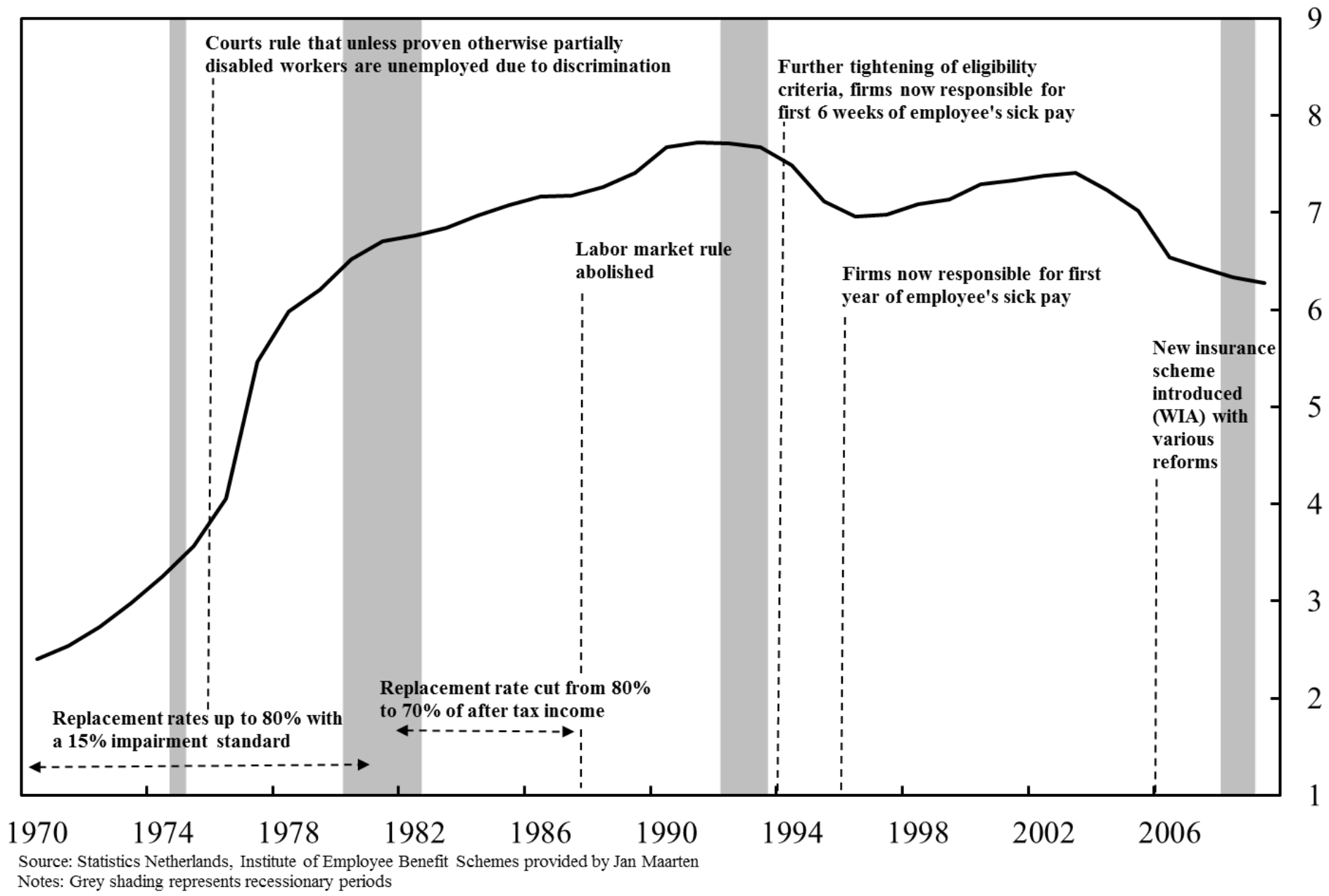

Source: Statistics Netherlands, Institute of Employee Benefit Schemes provided by Jan Maarten Notes: Grey shading represents recessionary periods 


\section{Panel C. Sweden DI Recipients per 100 Working Age}

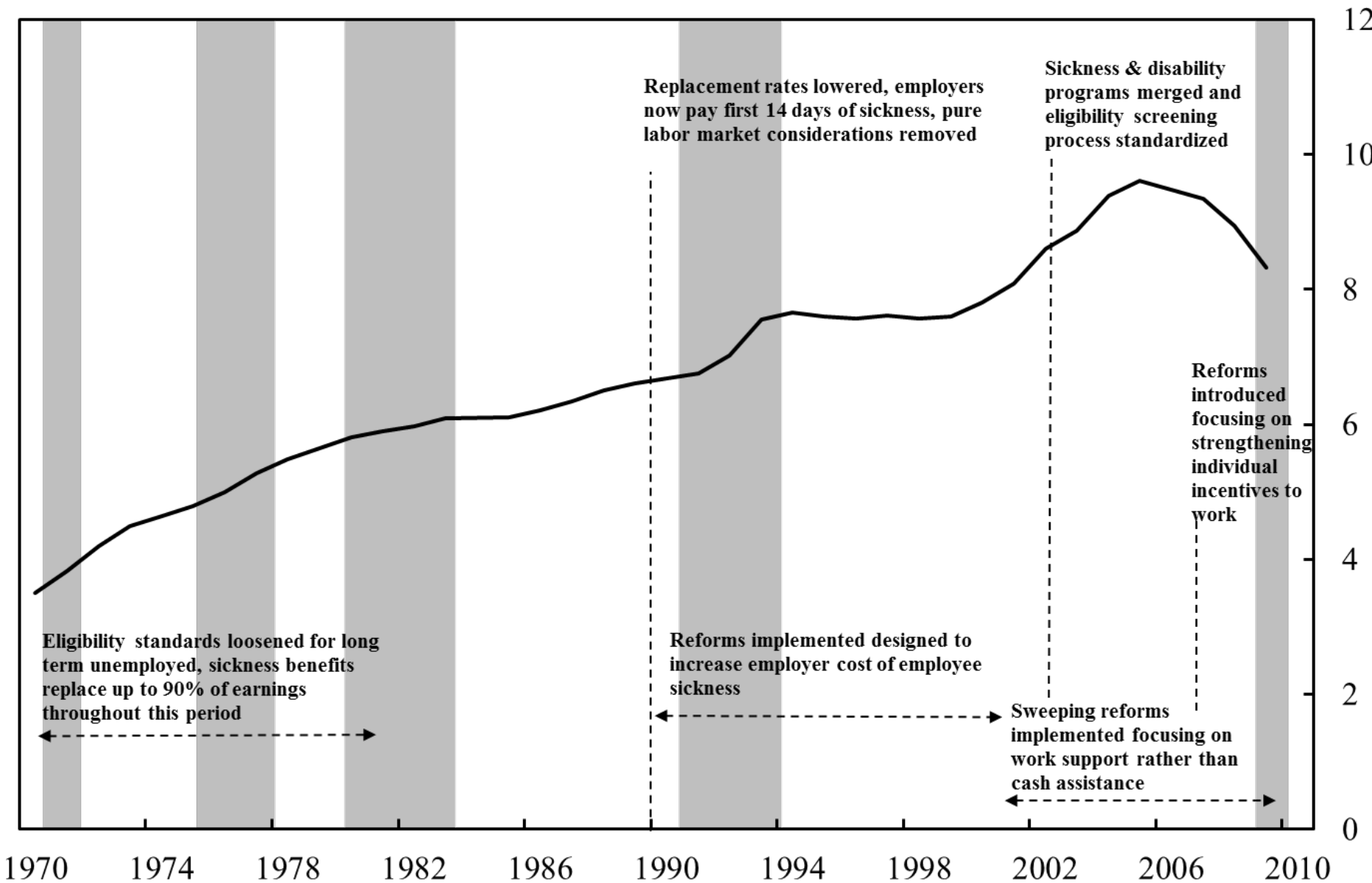

Source: Statistics Sweden and Swedish Social Insurance Agency yearbooks, provided by Lisa Laun Notes: Grey shading represents recessionary periods 
Panel D. United States DI Recipients per 100 Working Age

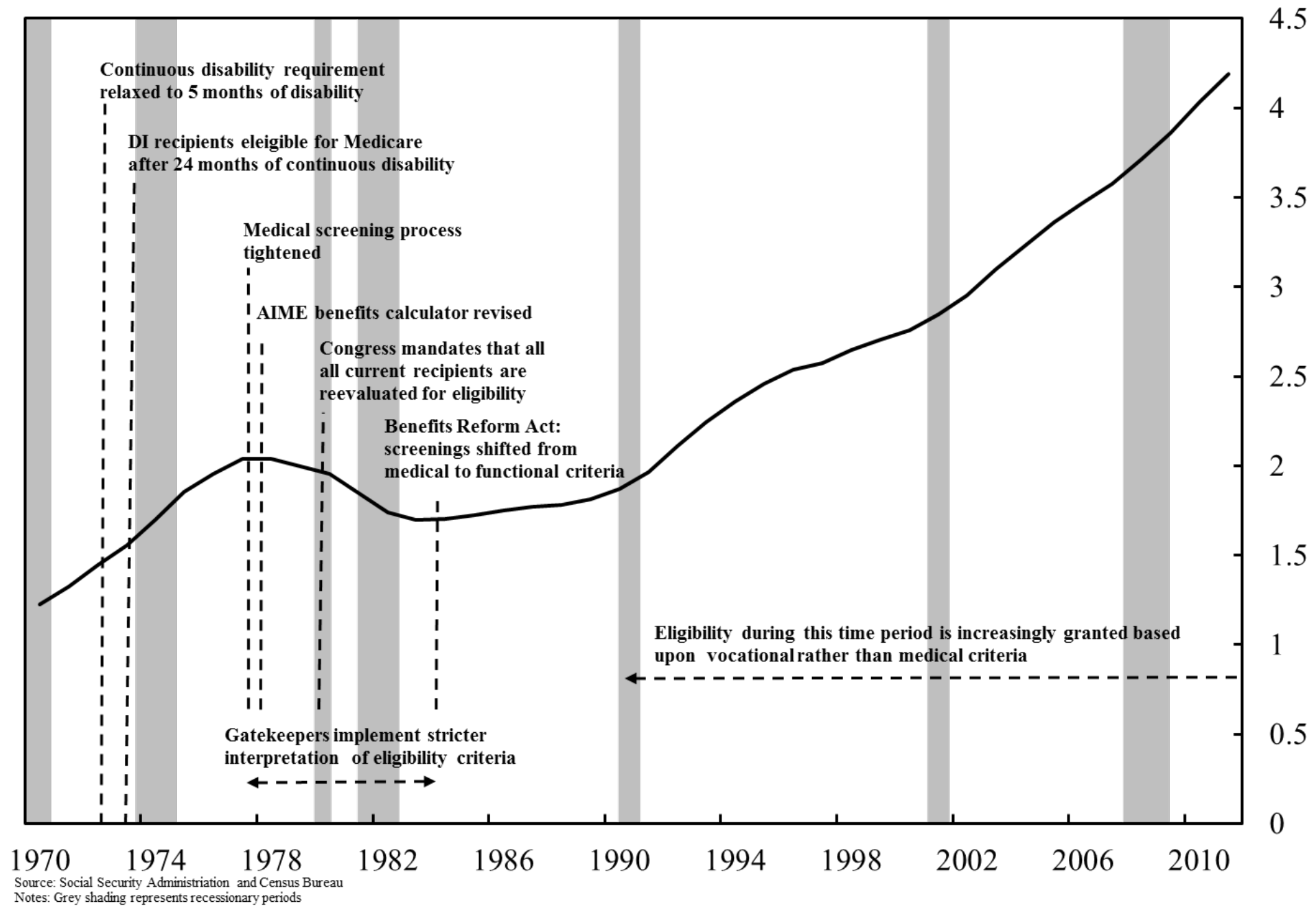


Figure 4. Development of New Private DI Policies in Germany

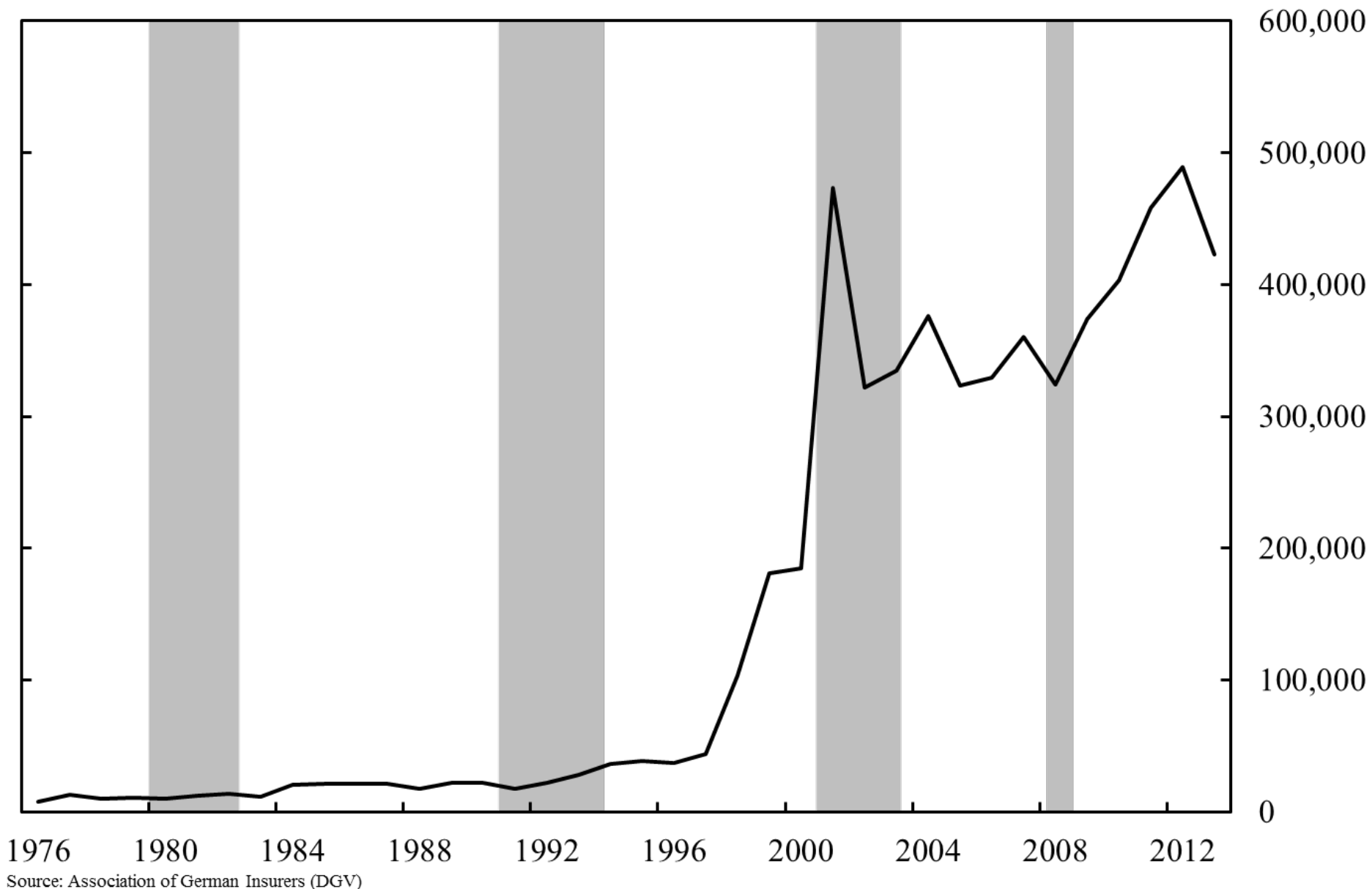

Source: Association of German Insurers (DGV)

Notes: Grey shading represents recessionary periods 
Table 1. Average Annual Growth in Disability Recipiency by Decade and Country ${ }^{1,2}$

1970-1979

1980-1989

1990-1999

2000-Final

1970-Final

\section{Germany}

1.69

$-1.79$

$-2.30$

$-1.61$

$-0.93$

\section{Ne the rlands}

11.45

1.79

$-0.34$

$-1.25$

2.69

Swe den
5.49
1.59
1.44
1.00
2.30

United States

5.65

$-0.91$

4.10

3.71

3.10

Source: Social Security Administration, US Census Bureau, , Statistics Sweden and Swedish Social Insurance Agency yearbooks, Statistics Netherlands, German Statutory Pension Insurance, German Federal Statistical Office, and the Institute of Employee Benefit Schemes

1.) See appendix for a summary of data years utilized across countries . 2.) Average is computed as the average year over year percent change in the recipiency rate within the given time period. For missing data a standard linear interpolation is used.

\section{Data Sources}

\section{Germany}

Deutsche Rentenversicherung (2014) on absolute number of WDP beneficiaries. Statistik der Deutschen Rentenversicherung (2014): “Rentenversicherung in Zeitreihen 2014,” http://forschung.deutscherentenversicherung.de, and upon request.

Statistisches Bundesamt (2014) on population between 15 and 65, unemployment rates, and people out of the labor force. https://www-genesis.destatis.de,

\section{Netherlands}

Historical population data are from Statistics Netherlands. http://www.cbs.nl/enGB/menu/home/default.htm

Disability insurance caseloads data are from the Institute of Employee Benefit Schemes, courtesy of Jan Maarten van Sonsbeek.

\section{Sweden}

Historical population estimates are from Statistics Sweden. http://scb.se

Disability Insurance prevalence data are from the Social Insurance Agency yearbooks, courtesy of Lisa Laun and Marten Palme.

\section{United States}

Historical population estimates are from the Census Bureau's Annual Estimates of Resident Population. http://www.census.gov

SSDI caseloads and covered workers data are from the Annual Statistical Supplement to the Social Security Bulletin. http://www.ssa.gov/policy/docs/statcomps/supplement/ 


\section{Table 2. Disability Program Parameters Across Countries as of 2013}

\section{Germany}

Summary of

Benefits Program

Merged sickness program with a disability program which makes a distinction between fully and partially disabled. Disability is determined by ability to work between 3 and 6 (partial), and less than 3 (full) hours per day. Coverage restricted to those who have paid social security taxes over their working lives with benefit levels tied to past earnings.

\section{Full or Partial} Benefits Program

Program differentiates between full and partial disability and awards benefits accordingly (see above). Coexisting employer mandate for businesses $>19$ employees: employ at least 5\% severely disabled or pay penalty.

\section{Eligibility Criteria}

Employer mandate guarantees $100 \%$ sick pay for first 6 weeks. Ongoing sickness is insured by statutory long-term sick pay---80\% of gross wage--up to 78 weeks. Legal obligation for employer "workplace reintegration management" during longterm sickness since 2004. DI applicants must present diagnoses documenting inability to work at least 6 hours/day. Basic social insurance principle: "rehabilitation before pension."

Benefits Conditional Yes, 3 out of last 5 years of coverage necessary on Contributions? before onset of disability. Waiting period of 5 years

\section{Netherlands} determined by doctor. above).

\section{Applicants must meet with} carried out by integration period.
Merged sickness program with a disability program which makes a strict distinction between fully an partially disabled. Those fully disabled receive guaranteed income until age 65 while partially disabled workers receive benefits conditional on work history and incapacity leve

Program differentiates between full (IVA) and partial disability (WGA) and awards benefits accordingly (see designated doctor (either a company doctor or agency) who evaluates incapacity. Several evaluations are supervisors on a rolling timeline during the initial two year sickness

Yes. Benefits levels are conditional on past earnings, number of weeks worked before, and the percentage of earnings the worker is deemed capable of earning currently with impairment.

Specific income tax deductions, 2 years of earlier regular retirement, subsidized public transportation and other public services designed to accommodate those who have long-term disabilities meeting specific criteria.

Means tested Social Assistance Program (SA) with benefit equal to minimum wage

\section{Sweden}

United States

Programs for the Disabled
Merged sickness program with a isability system with disability

benefits granted only to those

deemed to have permanent

reductions in work capacity.

No mandatory sickness program. Only those fully and permanently disabled eligible for benefits. Coverage restricted to those who have paid social security taxes over their working lives with benefit levels tied to past earnings.

Workers may receive sickness benefits in the event of a sickness with approval of a doctor), however disability insurance is only granted to those with a serious and permanent impairment that reduces work ability.

Sickness benefits are awarded for first 14 days with a doctor's approval and reevaluated along a rolling timeline with worker "check-ins." Disability benefits are only awarded after the SIA etermines work capacity is permanently reduced.

There are two types of benefits awarded. A universally guaranteed pension provides assistance to all those residing in Sweden. The earnings related pension is contingent upon weeks of work and past earnings.

Assistance Allowance, Car Worker's Comp and SSI and

Allowance and other programs are private disability insurance designed to accommodate those who have severe, long-term disabilities meeting specific criteria
Disability program designed to be last resort program for those with permanent and total disabilities.

Full disability program requiring applicants to be unable to perform any substantial gainful activity for at least one year.

Yes, sufficient quarters of coverage necessary as defined described in Social Security Administration 2013b. 


\section{Appendix A: Data Description and Sources}

\section{Data Description}

Summary of DI Data Availaibility Across Countries

$\begin{array}{ccccc} & \text { Germany } & \text { Netherlands } & \text { Sweden } & \text { United States } \\ \text { Initial Year } & 1970 & 1970 & 1970 & 1970 \\ \text { Final Year } & 2011 & 2009 & 2009 & 2011 \\ \text { Missing Years } & \text { gaps until '00 } & (-) & 1984 & 1981 \\ \text { Age Range of Working Population } & 16-64 & 15-65 & 16-64 & 16-64\end{array}$

\section{Data Sources}

\section{Germany}

Deutsche Rentenversicherung (2014) on absolute number of WDP beneficiaries. Statistik der Deutschen Rentenversicherung (2014): "Rentenversicherung in Zeitreihen 2014”, http://forschung.deutsche-rentenversicherung.de, and upon request.

Statistisches Bundesamt (2014) on population between 15 and 65, unemployment rates, and people out of the labor force. https://www-genesis.destatis.de,

\section{Netherlands}

Historical population data are from Statistics Netherlands. http://www.cbs.nl/enGB/menu/home/default.htm

Disability insurance caseloads data are from the Institute of Employee Benefit Schemes, courtesy of Jan Maarten van Sonsbeek.

\section{Sweden}

Historical population estimates are from Statistics Sweden. http://scb.se

Disability Insurance prevalence data are from the Social Insurance Agency yearbooks, courtesy of Lisa Laun and Marten Palme.

\section{United States}

Historical population estimates are from the Census Bureau's Annual Estimates of Resident Population. http://www.census.gov

SSDI caseloads and covered workers data are from the Annual Statistical Supplement to the Social Security Bulletin. http://www.ssa.gov/policy/docs/statcomps/supplement/ 